\title{
PEMENUHAN KEBUTUHAN PSIKOLOGIS PESERTA DIDIK SD/MI MELALUI PEMBELAJARAN TEMATIK-TERPADU
}

\author{
Andi Prastowo \\ Program Studi Pendidikan Guru Madrasah Ibtidaiyah \\ Fakultas Ilmu Tarbiyah dan Keguruan UIN Sunan Kalijaga Yogyakarta \\ E-mail:anditarbiyah@gmail.com
}

\begin{abstract}
Abstrak: Salah satu problematika pendidikan di Indonesia yang terbesar adalah rendahnya mutu pendidikan dasar di SD/MIyang sangat menentukan bagi kelanjutan pendidikan berikutnya. Pemerintah sesungguhnya telah mengupayakan berbagai kebijakan untuk mengatasi hal tersebut, namun terbukti belum menghasilkan perbaikan yang signifikan. Dilihat dari pengamatan di lapangan, problematika rendahnya mutu pendidikan ini tampaknya lebih karena faktor mutu proses pembelajaran yang masih jauh dari kebutuhanpsikologispeserta didik. Namun, dengan ditetapkannya Kurikulum 2013 yang mengamanatkan kepada setiap guru di di SD/MI agar menggunakan pendekatan pembelajaran tematik-terpadu adalah terobosan cerdas karena selaras dengan karakteristik berpikir peserta didik yang masih operasional konkret dan holistik.
\end{abstract}

Kata kunci: Mutu pendidikan, kebijakan, pembelajaran tematik-terpadu, berpikir holistik.

\begin{abstract}
One of thebiggest education problematika in Indonesia is lowering of quality of education of base in elementary school which is very determine to next education continuation. Real government have strived various policy to overcome the mentioned, proven but not yet yielded repair which is significant. Seen from perception in field, the problem of low quality of this education seems more because factor quality of study process which a long way off from psychological requirement of student. But, specified of Curriculum 2013 commending to every teacher in elementary school to be using approach of integrated learning is smart breakthrough because in harmony with characteristic think student which still operational of concrete and holistik.
\end{abstract}

Keywords: quality of education, policy, integrated learning, thinking, holistic.

\section{PENDAHULUAN}

Meskipun selama ini pemerintah di Indonesia telah melakukan berbagai upaya dalam meningkatkan mutu pendidikan namun ternyata hal ini masih menjadi problem utama yang hingga saat ini belum bisa dituntaskan. Sebagaimana diungkapkan Suryadi dan Budimansyahbahwa upaya peningkatan mutu pendidikan yang dilakukan oleh Pemerintah Indonesia pada semua jenis dan jenjang pendidikan, paling tidal sejak awal periode pembangunan nasional jangka panjang pertama, telahmengeluarkan biaya yang besar,tenagayang banyak, dan waktu yang cukup panjang. Namun demikian, selama itu pula dan sampai sekarang, mutu pendidikan masih tetap dirasakan sebagai tantangan yang cukup berat, mungkin tidak berbeda jauh dengan tantangan yang dirasakan masyarakat Indonesia 40 tahun yang lalu (Suryadi dan Budimansyah, 2009:127).

Keberadaan kualitas pendidikan dapat diidentifikasi antara lain dari peringkat kualitas SDM yang diukur berdasarkan IPM, prestasi belajar yang dicapai berdasarkan nilai hasil ujian nasional, dan hasil-hasil studi internasional seperti yang dilakukan oleh TIMS dan PISA. Berdasarkan hasil-hasil pengukuran ini Indonesia masih tergolong belum termasuk kategori 
tinggi. Peringkat IPM masih tertinggal dari sejumlah negara-negara di kawasan ASEANhasil ujian nasional juga angka kelulusannya masih di bawah angka enam, di bawah batas lulus di Malaysia dan Singapura, dan hasil studi internasional pun peringkatnya masih di bawah sejumlah negara ASEAN lain. Adapun masalah relevansi pendidikan dapat diidentifikasi dari masih tingginya angka pengangguran. Kualitas dan relevansi pendidikan ini berdampak pada kurangnya daya saing yang dapat diidentifikasi dari kemampuan SDM dalam memenangkan persaingan merebut pasar tenaga kerja (Ali, 2009:250-251).

Ada kemungkinan banyak faktor yang menyebabkan rendahnya mutu pendidikan suatu bangsa. Seperti di antaranya belum optimalnya upaya yang dilakukan pemerintah dalam melakukan peningkatan mutu pendidikan, mungkin juga karena upaya-upaya yang telah dilakukan telah berjalan relatif lebih lambat ketimbang aspirasi masyarakat tentang mutu pendidikan yang berubah dan berkembang dengan cepat. Di samping itu, mungkin juga kita telah memecahkan permasalahan yang keliru. Secara konseptual, mutu pendidikan dapat diartikan sebagai berikut: Kemampuan lembaga pendidikan dalam mendayagunakan sumbersumber pendidikan untuk meningkatkan kemampuan belajar seoptimal mungkin (Ace Suryadi, 1992). Dengan demikian, menurut Suryadi dan Budimansyah (2009:197)mutu pendidikan akan dapat diukur dengan pertanyaan sebagai berikut: "apakah anak didik atau lulusan pendidikan sudah memiliki kemampuan belajar seperti yang dimaksudkan”. Jika jawabannya 'tidak', maka upaya yang telah dilakukan dalam peningkatan mutu pendidikan cenderung telah membidik sasaran masalah yang keliru. Ini dalam pandangan William Dunn adalah jenis kesalahan ketiga (type three error), yaitusolving the wrong problem with the sophisticated methods of solution.

Di samping itu, sangat besar pula kemungkinan justru rendahnya mutu pendidikan nasional tersebut berakar dari rendahnya mutu pendidikan pada level Sekolah Dasar (SD)/Madrasah Ibtidaiyah(MI), sebagai pendidikan dasar yang menjadi landasan bagi pendidikan pada jenjang berikutnya. Jika pada level SD/MI ini saja mutu pendidikannya sudah buruk maka sangat besar kemungkinan bahwa mutu pendidikan pada level di atasnya tidak jauh berbeda. Logika ini mempertimbangkan sejumlah pendapat berikut ini. Pertama, Andi Prastowo(2013:13) yang menyatakan bahwa pendidikan dasar merupakan fondasi dasar dari semua jenjang sekolah selanjutnya. Kedua, Mohammad Ali, mantan Direktur Jenderal Pendidikan Islam Kementerian Agama, mengungkapkan bahwa tujuan penyelenggaraan pendidikan dasar (SD/MI dan SMP/MTs) adalah menyiapkan siswa agar menjadi manusia yang bermoral, menjadi warga negara yang mampu melaksanakan kewajibankewajibannya, dan menjadi orang dewasa yang mampu memperoleh pekerjaan. Dan, secara operasional, tujuan pokok pendidikan dasar adalah membantu siswa dalam mengembangkan kemampuan intelektual dan mentalnya, proses perkembangan sebagai individu yang mandiri, proses perkembangan sebagai makhluk sosial, belajar hidup menyesuaikan diri dengan berbagai perubahan, dan meningkatkan kreativitas (Ali, 2009:290-291). Dan, terakhir atau yang ketiga, pendapat A. Malik Fadjar (1999:34) yang menyatakan bahwa sekolah dasar atau madrasah ibtidaiyah ( $\mathrm{Ml}$ ) adalah pendidikandasar awal sebeium memasuki pendidikan dasar menengah, yaitu SMP/MTs. Pendidikan di sekolah dasar ataupun madrasah ibtidaiyah memegang peran penting dalam proses pembentukan kepribadian siswa, baik yang bersifat internal (bagaimana mempersepsi dirinya), eksternal (bagaimana mempersepsi lingkungannya), dan suprainternal (bagaimana mempersepsi dan menyikapi Tuhannya sebagai ciptaan-Nya.

Hal tersebut diperkuat oleh sejumlah indikasi di lapangan yang diungkap oleh Mohammad Ali (2009:252-259) sebagai berikut: pertama, masih rendahnya kualitas hasil belajar yang ditandai oleh standar kelulusan yang ditetapkan, yaitu 4,25 dari skala 10 dan 4,50 pada tahun 2008. Seorang siswa dinyatakan lulus meskipun hanya mampu menyerap mata pelajaran sebesar 4,25\%, Dengan standar kelulusan yang rendah pun masih banyak siswa yang tidak lulus pada Ujian Nasional 2007. Nilai kelulusan Ujian Nasional ini ternyata masih di bawah negara tetangga seperti Malaysia dan Singapura. Kondisi ini menunjukkan peserta didik kurang dapat bersaing dengan negara-negara tetangga. Walaupun angka kelulusan ujian nasional setiap tahun mengalami kenaikan, tetapi masih di 
bawah negara-negara Asia lain yang telah mematok angka di atas enam.

Indikasi kedua yakni angka ketidaklulusan ujian nasional (UN) tahun 2004/2005 lebih tinggi bila dibandingkan dengan tahun 2003/2004. Namun,.bila dilihat dari nilai rata-rata yang dicapai terdapat peningkatan yang cukup berarti yakni dari 5,55 tahun 2003/2004 menjadi 6,76 pada tahun 2004/2005. Angka mengulang kelas pada SD kelas awal juga cukup tinggi, yaitu I 7,92\%. Kondisi ini menunjukkan bahwa kesiapan memasuki SD masih rendah. Dilihat kecenderungan angka mengulang kelas menurut tingkat, makin tinggi tingkat kelas makin rendah angka mengulang kelas di I SD. Walaupun menunjukkan kecenderungan yang makin menurun setiap tiga tahun terakhir ini sekitar 700.000 siswa SD/ $\mathrm{Ml}$ putus sekolah setiap tahun.

Indikasi ketiga yakni dilihat dari kualifikasi guru yang mengajar di SD/MI maka pendidik pada jenjang SD dengan kualifikasi sarjana (S1) persentasenya masih sangat kecil. Sebagian besar pendidik SD mayoritas pendidikan berlatar belakang D1 dan D2. Seperti diungkap Balitbang Depdiknas RI tahun 2005/2006 bahwa dari sejumlah 1.346.846 orang guru SD yang berpendidikan Sarjana hanya 15.18\%, S2/S3 berjumlah 0,12 \%, D3 sebanyak 2,97\%, D2 berjumlah 48,95\%, dan D1 atau dibawahnya sebanyak 32,78\%. Indikasi keempat, yaitu menurut kelayakan mengajar guru, data Balitbang tahun 2006 menyebutkan bahwa persentase guru yang tidak layak mengajar terutama di jenjang SD mencapai sekitar 1.140 .836 orang (84,70\%) baik pada sekolah negeri maupun swasta. Rinciannya sebagai berikut: untuk SD Negeri guru yang layak sejumlah 14,37\% dan 85,63\% tidak layak; sedangkan untuk SD Swasta guru yang layak 25,89\% dan guru yang tidak layak 74,11\%.

Dari empat indikasi yang disebutkan oleh Mohammad Ali tersebut sudah dapat dilihat bahwa besar kemungkinan bahwa mutu pendidikan pada jenjang Sekolah Dasar/Madrasah Ibtidaiyah yang masih begitu rendah ditambah dengan peranannya yang sangat penting bagi pendidikan pada jenjang berikutnya sebagaimana dikemukakan Prastowo, Mohammad Ali, dan A. Malik Fadjar maka buruknya mutu pendidikan dasar di SD/MI memiliki kontribusi yang besar dalam menentukan rendahnya mutu pen- didikan nasional. Untuk itu, perlu dikembangkankan solusi kebijakan terbaik untuk mengatasi problem rendahnya mutu pendidikan pada Sekolah Dasar/Madrasah Ibtidaiyah agar benarbenar sesuai dengan masalah yang semestinya di atasi sehingga tepat sesuai sasaran, efektif dan efisien.

Menurut Karwati dan Triansa (2013:51), upaya peningkatan mutu bidang pendidikan difokuskan kepada mutu proses pendidikan. Inti dari proses pendidikan adalah pembelajaran peserta didik. Proses pembelajaran ini mencakup sejumlah unsur utama yang mendasar yang membentuk mutu pembelajaran. Unsur-unsur tersebut adalah tujuan pembelajaran, isis kurikulum, guru, sarana dan prasarana, dana, manajemen dan evaluasi. Tujuan penting yang diperlukan dalam peningkatan mutu adalah ketepatan dan kejelasan.

Hal tersebut juga ditegaskan Zamroni (2011:136-137), bahwa peningkatan mutu sekolah, dapat disebut sebagai suatu perpaduan antara knowledge-skill, art, dan entrepreneurship. Suatu perpaduan yang diperlukan untuk membangun keseimbangan antara berbagai tekanan, tuntutan, keinginan, gagasan, pendekatan dan praktek. Perpaduan tersebut di atas berujung pada bagaimana proses pembelajaran dilaksanakan sehingga terwujud proses pembelajaran yang berkualitas. Semua upaya peningkatan mutu sekolah harus melewati variabel ini. Proses pembelajaran merupakan faktor yang langsung menentukan kualitas sekolah. Oleh karena iu, peningkatan mutu pembelajaran merupakan inti dari reformasi pendidikan di negara manapun.

Dalam upaya peningkatan mutu proses pembelajaran tersebut, ada banyak variabel yang saling berinteraksi secara kompleks dan rumit. Variabel-variabel dalam banyak proses interaksi antara guru dan peserta didik berkaitan dengan suatu materi tertentu yang tidak dapat dikendalikan secara pasti.Terdapat keterkaitan berbagai materi yang sulit untuk diindentifikasi mana yang mempengaruhi dan mana yang dipengaruhi. Hasil pembelajaran tidak bisa diestimasi secara matematis, pasti (Zamroni, 2011:136137).Namun, menurut La Iru dan La Ode Safiun Arihi (2012:1), kompetensi dan tujuan pembelajaran akan tercapai secara optimalapabila pemilihan pendekatan, metode, strategi, dan 
model-model pembelajaran tepat dan disesuaikan dengan materi, tingkat kemampuan siswa, karakteristik siswa. Dengan kata lain, ketepatan dalam menentukan pendekatan pembelajaran menjadi faktor yang penting dalam upaya penngkata mutu proses pembelajaran.

Mulai tahun 2013, pemerintah menetapkan kebijakan baru seiring dengan implementasi Kurikulum 2013, yaitu penggunaan pendekatan pembelajaran ematik-terpadu untuk SD/MI. Seperti disebutkan dalamlampiran Peraturan Menteri Pendidikan dan Kebudayaan Republik Indonesia No. 65 Tahun 2013 tentang Standar Proses Pendidikan Dasar dan Menengah bahwa kegiatan pembelajaran untuk SD/MI/SDLB/ Paket A menggunakan pendekatan pembelajaran tematik-terpadu. Hal serupa juga dijelaskan dalam Lampiran Permendikbud RI No. 67 Tahun 2013 tentang Kerangka Dasar dan Struktur Kurikulum Sekolah Dasa / Madrasah Ibtdaiyah bahwa untuk proses pembelajaran pada jenjang SD/MI dari kelas 1 hingga kelas VI menggunakan pembelajaran tematik-terpadu. Pembelajaran tematik-terpadu merupakan pendekatan pembelajaran yang memadukan bebagai kompetensi dari berbagai mata pelajaran ke dalam berbagai tema (Madjid, 2014:49).

Keputusan pemerintah untuk menggunakan pendekatan pembelajaran tematik-terpadu ini tampaknya relevan dengan upaya peningkatan mutu proses pembelajaran di SD/MI. Karena, menurut Ridwan Abdullah Sani (2013:vii-viii) perbaikan mutu seharusnya dilakukan dalam upaya memenuhi kebutuhan peserta didik untuk hidup di masyarakat pada era persaingan dengan bangsa asing yang mulai merambah ke Indonesia. Adapun pemaduan melalui pembelajaran tematik terpadu tersebut yang dilakukan melalui dua hal yaitu integrasi sikap, keterampilan, dan pengetahuan dalam proses pembelajaran dan terpadunya berbagai konsep dasar yang berkaitan menjadikan peserta didik tidak belajar konsep dasar secara parsial akan tetapi justru memberikan makna yang utuh. Di samping itu, pemaduan ini secara psikologis memberikan keuntungan bagi kemampuan berpikir selanjutnya (Madjid, 2014:50). Hal ini tampaknya juga sesuai dengan karakteristik dunia anak yang dalam tahap perkembangan mentalnya selalu dimulai dari tahap berpikir nyata dalam kehidupan sehari-hari yang memandang obyek yang ada di sekelilingnya secara utuh (Susanto, 2013:94).

Berdasarkan uraian di atas, penulis melihat bahwa kebijakan pemerintah berkaitan dengan penggunaan pendekatan pembelajaran tematikterpadu di SD/MI tampaknya merupakan upaya yang akan memenuhi kebutuhan psikologis peserta didik di SD/MI. Jika kebutuhan perkembangan peserta didik terpenuhi dan terlayani dengan efektif dan efisien maka sangat besar kemungkinan bahwa mutu proses pembelajaran di SD/MI kedepannya akan meningkat. Berangkat dari sinilah penulis memandang penting kajian secara lebih mendalam tentang kebijakan pendidikan penerapan pembelajaran tematik-terpadu di SD/MI dari perspektif psikologi pendidikan. Adapun beberapa rumusan masalah yang dikaji di antaranya, pertama, bagaimanakah karakteristik perkembangan peserta didik di SD/MI?, kedua, bagaimanakah kebijakan pembelajaran tematik-terpadu di SD/ MI?, dan ketiga, sejauhmana relevansi kebijakan pembelajaran tematik-terpadu bagi pemenuhan kebutuhan perkembangan peserta didik di SD/ MI? Kajian dalam artikel ini dilakukan dengan menggunakan library research (studi kepustakaan) dengan menggunakan metode analisis konten kebijakan. Adapun untuk melihat sejauh mana kebijakan penerapan pembelajaran tematik-terpadu di SD/MI relevan dengan kebutuhan perkembangan peserta didik menggunakan pendekatan psikologi pendidikan.

\section{Karakteristik Perkembangan Siswa SD/MI}

Kajian pada segmen pertama ini berangkat dari sebuah asumsi bahwa pemahaman yang baik terhadap karakteristik kebutuhan perkembangan peserta didik di SD/MI merupakan kunci bagi keberhasilan proses pembelajaran. Sebagaimana diungkapkan Hamzah B. Uno dan Nurdin Mohamad (2011:261) bahwa dengan memahami siswa dengan baik, diharapkan kita dapat memberikan layanan pendidikan yang tepat dan bermanfaat bagi masing-masing anak. Selain itu, pentingnya memahami dan memenuhi kebutuhan perkembangan peserta didik di SD/MI bagi guru menurut Sumantri dalam Ahmad Susanto (2013:71), yaitu sebagai berikut:pertama, kita akan memperoleh ekspektasi yang nyata tentang anak dan remaja; kedua, pengetahuan tentang psikologi perkembangan anak mem- 
bantu kita untuk merespons sebagaimana mestinya pada perilaku tertentu pada seorang anak; ketiga, pengetahuan tentang perkembangan anak akan membantu mengenali berbagai penyimpangan dari perkembangan yang normal; keempat, dengan mempelajari perkembangan anak akan membantu memahami diri sendiri.

Karakteristik perkembangan anak pada usia SDbiasanyapertumbuhan fisiknya telah mencapai kematangan. Mereka telah mampu mengontrol tubuh dan keseimbangannya. Mereka telah dapat melompat dengan kaki secara bergantian, dapat mengendarai sepeda roda dua, dapat menangkap bola dan telah berkembang koordinasi tangan dan matanya untuk dapat memegang pensil maupun memegang gunting. Selain itu, perkembangan sosial anak yang berada pada usia kelas awal SD, antara lain mereka telah dapat menunjukkan keakuannya tentang jenis kelaminnya, telah mulai berkompetisi dengan teman sebaya, mempunyai sahabat, telah mampu berbagi, dan mandiri (Madjid, 2014:7).

Untuk perkembangan bahasa, bagi anak usia sekolah dasar minimal dapat menguasai tiga kategori, yaitu:pertama, dapat membuat kalimat yang lebih sempurna; kedua, dapat membuat kalimat majemuk; dan ketiga, dapat menyusun dan mengajukan pertanyaan. Di samping itu, menurut Syamsu Yusuf dalam Ahmad Susanto (2013:74-76), pada usia sekolah dasar ini anak mulai belajar mengendalikan dan mengontrol ekspresi emosinya. Syamsu juga mengatakan bahwa karakteristik emosi yang stabil (sehat) ditandai dengan menunjukkan wafah yang ceria, bergaul dengan teman secara baik, dapat berkonsentrasi dalam belajar, bersifat respek (menghargai) terhadap diri sendiri dan orang lain. Adapun perkembangan moral pada anak usia SD/MIyaitumereka sudah dapat mengikuti peraturan atau tuntutan dari orangtua atau lingkungan sosialnya. Pada akhir usia ini (usia 11 atau 12 tahun), anak bahkan sudah dapat memahami alasan yang mendasari suatu peraturan. Di samping itu, anak sudah dapat mengasosiasikan setiap bentuk perilaku dengan konsep benar salah atau baik buruk.

Menurut Hamzah B. Uno dan Nurdin Mohamad (2011:282), sebagai makhluk psiko-fisik, anak-anak sejak bayi sudah memiliki kebutuhan-kebutuhan dasar, yaitu seperti kebutuhan fisik dan psikis. Dalam proses pertumbuhan dan perkembangan seorang anak menuju kedewasaan, terjadi perubahan-perubahan kebutuhan seperti di atas menjadi lebih besar. Dan, kebutuhan sosial psikologis seseorang akan lebih banyak dibandingkan kebutuhan fisiknya sejalan dengan usianya.

Ada dua teori kebutuhan yang perlu diungkapkan untuk memahami kebutuhan peserta didik SD/MI, yaitu teori kebutuhan yang dikembangkan oleh Maslow dan teori kebutuhan yang dikembangkan oleh Lindgren. Menurut teori kebutuhan Maslow, kebutuhan yang rendah dalam hierakhi kebutuhan individu paling tidak harus terpenuhi sebagian sebelum kebutuhan yang lebih tinggi pada hierarkhi tersebut menjadi sumber motivasi yang penting. Kebutuhan mendasar seorang individu adalah kebutuhan fisiologis, lalu kebutuhan individu berkembang dengan kebutuhan ingin dilindungi, kebutuhan akan cinta dan rasa memiliki, dan seterusnya sehingga kebutuhan tersebut mencapai klimaks pada kebutuhan mengaktualisasikan diri. Tahapan tersebut tidak bersifat statis. Setiap kebutuhan bisa semakin meningkat atau melemah tergantung dari perkembangan masing-masing individu. Sedangkan menurut Lindgren kebutuhan dasar individu dikelompokkan menjadi 4 (empat) aspek, yaitu untuk kebutuhan paling dasar (pertama), yaitu kebutuhan jasmaniah, termasuk keamanan dan pertahanan diri; tingkat kedua, kebutuhan perhatian dan kasih sayang; tingkat ketiga, kebutuhan untuk memiliki; dan tingkat keempat, kebutuhan aktualisasi diri (Uno dan Mohamad, 2011:282-285).

Pada masa kanak-kanak akhir dan anak sekolah, yaitu usia enam hingga dua belas tahun, mereka memiliki sejumlah tugas perkembangan, yaitu sebagai berikut: pertama, belajar keterampilan fisik untuk pertandingan biasa sehari- hari; kedua, membentuk sikap yang sehat terhadap dirinya sebagai organisme yang sedang tumbuh kembang; ketiga, belajar bergaul dengan teman-teman sebayanya; keempat, belajar peranan sosial yang sesuai sebagai pria atau wanita; kelima, mengembangkan konsep-konsep yang perlu bagi kehidupan sehari-hari; keenam, mengembangkan kata hati, moralitas, dan suatu skala nilai-nilai; ketujuh, mencapai kebebasan pribadi; dan kedelapan, mengembangkan sikapsikap terhadap kelompok-kelompok dan institusi-institusi sosial. Menurut Havighurst tugas- 
tugas perkembangan ini merupakan tugas yang muncul pada saat atau di sekitar suatu periode tertentu dari kehidupan individu yang jika berhasil akan menimbulkan rasa bangga dan membawake arah keberhasilan dalam melaksanakan tugas-tugas berikutnya (Susanto, 2013:72).

Sementara itu, tahap perkembangan tingkah laku belajar anak Sekolah Dasar atau Madrasah Ibtidaiyah sangat dipengaruhi oleh berbagai aspek dari dalam diri dan lingkungan yang ada di sekitarnya. Kedua hal tersebut tidak mungkin dipisahkan karena memang proses belajar terjadi dalam interaksi diri siswa dengan lingkungannya (Prastowo, 2013:33-34). Seperti diungkapkan oleh Piaget,setiap anak memiliki cara tersendiri dalam menginterpretasikan dan beradaptasi dengan lingkungannya (Rusman, 2010:250).

Dikatakan pula oleh Piaget bahwa pada diri anak terdapat struktur kognitif yang disebut skema. Dalam memahami dunia mereka secara aktif, anak-anak menggunakan skema (schema). Skema bisa merentang mulai dari skema sederhana (contohnya, seperti skema seekor gajah) sampai skema kompleks (seperti skema tentang bagaimana terjadinya alam semesta). Ditegaskan Piaget bahwa ada dua proses yang bertanggungjawab atas cara anak menggunakan dan mengadaptasi skema mereka, yaitu asimilasi dan akomodasi. Asimilasi terjadi ketika seorang anak memasukkan pengetahuan baru ke dalam pengetahuan yang sudah ada. Akomodasi terjadi ketika anak menyesuaikan diri pada informasi baru, yaitu anak menyesuaikan skema mereka dengan lingkungannya (Santrock, 2007:46). Kedua proses tersebut apabila berlangsung secara terus-menerus akan membuat pengetahuan lama dan pengetahuan baru menjadi seimbang. Dengan cara seperti itu anak secara bertahap dapat membangun pengetahuan melalui interaksi dengan lingkungan sekitarnya (Rusman, 2010:250).Dengan kata lain, proses belajar dapat berlangsung jika terjadi proses pengolahan data yang aktif di pihak pembelajar. Pengolahan data yang aktif merupakan aktivitas lanjutan dari kegiatan mencari informasi dan dilanjutkan dengan kegiatan penemuan (Madjid, 2014:7).

Selaras dengan pendapat Piaget bahwa kematangan biopsikologis seseorang memiliki tingkatan-tingkatan, maka kematangan biopsikologis peserta didik di SD/MI juga berting- kat-tingkat. Tingkatan perkembangan intelektual peserta didik SD/MI merujuk pada pendapat Piaget memiliki ciri-ciri yaitu: tahap pra-operasional (2-7 tahun), tahap berpikir pra-konseptual (2-4 tahun) yang ditandai dengan mulainya adaptasi terhadap simbol, mulai dan tingkah laku berbahasa, aktivitas imitasi dan permainan. Kemudian pada tahap berpikir intuitif (4-7 tahun) ditandai oleh berpikir pralogis yaitu antara operasional konkret dengan prakonseptual. Pada tahap ini perkembangan ingatan peserta didik sudah mulai mantap, tetapi kemampuan berpikir deduktif dan induktif masih lemah/belum mantap.Perkembangan intelektual siswa sekolah dasar berada pada tahap operasional konkret (7-11 tahun) yang ditandai oleh kemampuan berpikir konkret dan mendalam, mampu mengklasifikasi dan mengontrol persepsinya. Pada tahap ini, perkembangan kemampuan berpikir siswa sudah mantap, kemampuan skema asimilasinya sudah lebih tinggi dalam melakukan suatu koordinasi yang konsisten antar skema (Madjid, 2014:8). Kemudian, pada usia 11 tahun hingga dewasa, peserta didik memiliki karakteristik perkembangan intelektual yang disebut tahap operasional formal. Pada tahap ini peserta didik sudah mapu berpikir secara lebih abstrak, idealistik, dan logis (Santrock, 2007:47-48). Berdasarkan tahapan tersebut, siswa sekolah dasar kelas I-VI memiliki tingkatan intelektual operasional konkret dan siswa kelas enam memiliki tingkatan operasional formal (Madjid, 2014:8).

Di samping itu, kecenderungan peserta didik di SD/MI ketika belajar memunyai tiga karakteristik yang menonjol yaitu: konkret, integratif, dan hierakhis. Dijelaskan secara detail oleh Rusman (2010:251-252) ketiga hal tersebut sebagai berikut: pertama, konkret maksudnya proses belajar beranjak dari hal-hal yang konkret dengan titik penekanan pada pemanfaatan lingkungan sebagai sumber belajar yang dapat dioptimalkan untuk pencapaian proses dan hasil pembelajaran yang berkualitas bagi anak usia SD/MI. Penggunaan lingkungan akan menghasilkan proses dan hasil belajar yang lebih bermakna dan bernilai, karenasiswa dihadapkan dengan peristiwa dan keadaan yang sebenarnya, keadaan yang alami, sehingga lebih nyata, lebih faktual, lebih bermakna, dan kebenaranya lebih dapat dipertanggungjawabkan.

Kedua, integratif maksudnya adalah me- 
mandang sesuatu yang dipelajari sebagai suatu keutuhan dan terpadu. Anak usia SD/MI belum mampu memilah-milah konsep dari berbagai disiplin ilmu, hal ini menggambarkan cara berpikir deduktif. Dengan demikian, keterpaduan konsep tidak dipilah-pilah dalam berbagai disiplin ilmu, tetapi dikait-kaitkan menjadi pengalaman belajar yang bermakna (meaningful learning). Ketiga, hierakhis maksudnya adalah berkembang secara bertahap mulai dari hal-hal yang sederhana ke hal-hal yang lebih kompleks. Oleh karena itu, dalam hal ini persoalanpersoalan seperti urutan logis, keterkaitan antar materi pelajaran, dan cakupan keluasan materi pelajaran menjadi penting dan sangat perlu untuk diperhatikan.

Kemampuan berpikir yang dimiliki oleh siswa sekolah dasar tersebut akan memengaruhi seluruh kegiatan pembelajaran yang diselenggarakan guru. Oleh karena itu, kegiatan pembelajaran pendidikan Sains, Bahasa Indonesia, dan Budi Pekerti, serta mata pelajaran lainnya diarahkan pada pendekatan "meaningfullearning” yang didasarkan kepada pengembangan kemampuan berpikir disesuaikan dengan biopsikologis siswa yang hendaknya dijadikan tolok ukur guru, baik dalam pengembangan materi, strategi mengajar, pendekatan, media, maupun dalam melakukan evaluasi hasil belajar (Madjid, 2014:8).

Dari uraian tersebut dapat disimpulkan bahwa karakteristik perkembangan peserta didik di SD/MI dapat dipilah menjadi dua macam yaitu perkembangan pada aspek jasmaniah dan perkembangan pada aspek mental. Pada aspek jasmaniah, peserta didik SD/MI telah memiliki kematangan sehingga mampu mengontrol tubuh dan keseimbangannya. Pada aspek mental yang meliputi perkembangan inteletual, bahasa, sosial, emosi, dan moral keagamaan , peserta didik SD/MI secara intelektual berada pada tahap perkembangan operasional konkret (kelas I-V) dan operasional formal (kelas VI), yang memiliki kecenderungan belajar bersifat konkret, integratif, dan hierarkhis. Dari aspek bahasa, mereka telah mampu membuat kalimat sempurna, bahkan kalimat majemuk, dan juga dapat mengajukan pertanyaan. Dari aspek sosial, peserta didik di SD/MI mulai membentuk ikatan baru dengan teman sebaya dan mulai mampu menyesuaikan diri sendiri kepada sikap bekerjasama. Mereka secara emosi juga telah mulai belajar mengendalikan dan mengontrol ekspresi emosinya. Sedangkan pada aspek moral, peserta didik SD/MI sudah dapat mengikuti peraturan atau tuntuntan dari orangtua atau lingkungannya , bahkan di akhir jenjang SD/MI juga mampu memahami alasan yang mendasari suatu peraturan.

\section{KEBIJAKAN PEMBELAJARAN TEMATIK-TERPADU UNTUK SD/MI DALAM KURIKULUM 2013}

Kebijakan tentang penggunaan pendekatan pembelajaran tematik-terpadu untuk SD/MI terlahir seiring dengan kebijakan Kurikulum 2013 untuk pendidikan dasar dan menengah. Menurut Ridwan Abdullah Sani, pengembangan Kurikulum 2013 merupakan upaya peningkatan mutu pendidikan untuk menghasilkan lulusan yang kreatif dan mampu menghadapi kehidupan di masa yang akan datang (Sani, 2013:vii-viii). Hal serupa juga diungkapkan Abdul Madjid, pengembangan Kurikulum 2013 adalah bagian dari strategi meningkatkan capaian pendidikan. Di samping kurikulum, terdapat sejumlah faktor di antaranya lama siswa bersekolah; lama siswa tinggal di sekolah; pembelajaran siswa aktif berbasis kompetensi; buku pegangan dan peranan guru sebagai ujung tombak pelaksanaan pendidikan (Madjid, 2014:27-28).

Orientasi Kurikulum 2013 adalah terjadinya peningkatan dan keseimbangan antara kompetensi sikap(attitude),keterampilan(skil l) dan pengetahuan(knowledge).Hal ini sejalan dengan amanat UU No. 20 Tahun 2003 sebagaimana tersurat dalam penjelasan Pasal 35, yaitu kompetensi lulusan merupakan kualifikasi kemampuan lulusan yang mencakup sikap, pengetahuan, dan keterampilan sesuai dengan standar nasional yang telah disepakati. Hal ini sejalan pula dengan pengembangan kurikulum berbasis kompetensi yang telah dirintis pada tahun 2004 dengan mencakup kompetensi sikap, pengetahuan, dan keterampilan secara terpadu (Madjid, 2014:28).

Pengembangan kurikulum 2013 tidak terlepas dari berbagai permasalahan yang dihadapi oleh Kurikulum 2006 atau biasa dikenal dengan Kurikulum Tingkat Satuan Pendidikan yaitu sebagai berikut: pertama,konten kurikulum masih terlalu padat yang ditunjukkan dengan 
banyaknya mata pelajaran dan banyak materi vang keluasan dan kesukarannya melampaui tingkat perkembangan usia anak; kedua, kurikulum belum sepenuhnya berbasis kompetensi sesuai dengan tuntutan fungsi dan tujuan pendidikan nasional; ketiga, kompetensi belum menggambarkan secara holistik domain sikap, keterampilan, dan pengetahuan; keempat, beberapa kompetensi yang dibutuhkan sesuai dengan perkembangan kebutuhan (misalnya pendidikan karakter, metodologi pembelajaran aktif, keseimbangan soft skills dan hard skills, kewirausahaan) belum terakomodasi di dalam kurikulum; kelima, kurikulum belum peka dan tanggap terhadap perubahan sosial yang terjadi pada tingkat lokal, nasional, maupun global; keenam, standar proses pembelajaran belum menggambarkan urutan pembelajaran yang rinci sehingga membuka peluang penafsiran yang beranekaragam dan berujung pada pembelajaran yang berpusat pada guru; ketujuh, standar penilaian belum mengarahkan kepada penilaian berbasis kompetensi (sikap, ketrampilan, dan pengetahuan) dan belum tegas menuntut adanya remediasi secara berkala; dan kedelapan, dengan KTSP memerlukan dokumen kurikulum yang lebih rinci agar tidak menimbulkan multitafsir (Madjid, 2014:28-29).

Sementara itu,kebijakan bahwa kegiatan pembelajaran di SD/MI harus menggunakan pendekatan pembelajaran tematik-terpadu ini didasarkan pada Peraturan Pemerintah No. 32 Tahun 2013 Pasal 19 Ayat (1) yang menyebutkan, "Proses Pembelajaran pada satuan pendidikan diselenggarakan secara interaktif, inspiratif, menyenangkan, menantang, memotivasi Peserta Didik untuk berpartisipasi aktif, serta memberikan ruang yang cukup bagi prakarsa, kreativitas, dan kemandirian sesuai dengan bakat, minat, dan perkembangan fisik serta psikologis Peserta Didik”.Kemudian secara lebih spesifik diatur dalam Permendikbud RI No.67 Tahun 2013 tentang Kerangka Dasar dan Struktur Kurikulum Sekolah Dasar / Madrasah Ibtidaiyah pada lampirannya menyebutkan bahwa kurikulum 2013 dikembangkan dengan penyempurnaan pola salah satunya sebagai berikut,"Pola pembelajaran ilmu pengetahuan tunggal (monodiscipline) menjadi pembelajaran ilmu pengetahuan jamak (multidisciplines)". Sedangkan pada Bab III Poin E dalam lampiran Permendikbud RI No.67
Tahun 2013 ini disebutkan:

Pelaksanaan Kurikulum 2013 pada Sekolah Dasar/Madrasah Ibtidaiyah dilakukan melalui pembelajaran dengan pendekatan tematik-terpadu dari Kelas I sampai Kelas VI. Matapelajaran Pendidikan Agama dan Budi Pekerti dikecualikan untuk tidak menggunakan pembelajaran tematik-terpadu.

Dalam penjelasan Poin E Bab III lampiran Permendikbud RI No.67 Tahun 2013 diungkapkan pula bahwa maksud dari pendekatan tematik-terpadu yaitu pendekatan pembelajaran yang mengintegrasikan berbagai kompetensi dari berbagai matapelajaran ke dalam berbagai tema.Pendekatan yang digunakan untuk mengintegrasikan kompetensi dasar dari berbagai matapelajaran yaitu intra-disipliner, interdisipliner, multi-disipliner, dan trans-disipliner. Integrasi intra-disipliner dilakukan dengan cara mengintegrasikan dimensi sikap, pengetahuan, dan keterampilan menjadi satu kesatuan yang utuh di setiap matapelajaran. Integrasi inter-disipliner dilakukan dengan menggabungkan kompetensi-kompetensi dasar beberapa matapelajaran agar terkait satu dengan yang lainnya, sehingga dapat saling memperkuat, menghindari terjadinya tumpang tindih, dan menjaga keselarasan pembelajaran. Integrasi multi-disipliner dilakukan tanpa menggabungkan kompetensi dasar tiap matapelajaran sehingga tiap matapelajaran masih memiliki kompetensi dasarnya sendiri. Integrasi trans-disipliner dilakukan dengan mengaitkan berbagai matapelajaran yang ada dengan permasalahan-permasalahan yang dijumpai di sekitarnya sehingga pembelajaran menjadi kontekstual.

Lebih lanjut menurut lampiran Permendikbud RI No.67 Tahun 2013 tersebut juga ditegaskan bahwa tema merajut makna berbagai konsep dasar sehingga peserta didik tidak belajar konsep dasar secara parsial. Dengan demikian, pembelajarannya memberikan makna yang utuh kepada peserta didik seperti tercermin pada berbagai tema yang tersedia. Tematik terpadu disusun berdasarkan gabungan proses integrasi seperti dijelaskan di atas sehingga berbeda dengan pengertian tematik seperti yang diperkenalkan pada kurikulum sebelumnya.

Selain itu, pembelajaran tematik-terpadu ini juga diperkaya dengan penempatan matapelajaran Bahasa Indonesia di Kelas I, II, dan 
III sebagai penghela matapelajaran lain. Melalui perumusan Kompetensi Inti sebagai pengikat berbagai matapelajaran dalam satu kelas dan tema sebagai pokok bahasannya, sehingga penempatan matapelajaran Bahasa Indonesia sebagai penghela matapelajaran lain menjadi sangat memungkinkan. Penguatan peran matapelajaran Bahasa Indonesia dilakukan secara utuh melalui penggabungan kompetensi dasar matapelajaran Ilmu Pengetahuan Sosial dan Ilmu Pengetahuan Alam ke dalam matapelajaran Bahasa Indonesia. Kedua ilmu pengetahuan tersebut menyebabkan pelajaran Bahasa Indonesia menjadi kontekstual, sehingga pembelajaran Bahasa Indonesia menjadi lebih menarik (Lampiran Permendikbud RI No.67 Tahun 2013).

Pendekatan sains seperti itu terutama di Kelas I, II, dan III menyebabkan semua matapelajaran yang diajarkan akan diwarnai oleh matapelajaran Ilmu Pengetahuan Sosial dan Ilmu Pengetahuan Alam. Untuk kemudahan pengorganisasiannya, kompetensi-kompetensi dasar kedua matapelajaran ini diintegrasikan ke matapelajaran lain (integrasi inter-disipliner). Kompetensi dasar matapelajaran Ilmu Pengetahuan Alam diintegrasikan ke kompetensi dasar matapelajaran Bahasa Indonesia dan kompetensi dasar matapelajaran MatematikaKompetensi dasar matapelajaran Ilmu Pengetahuan Sosial diintegrasikan ke kompetensi dasar matapelajaran Bahasa Indonesia, ke kompetensi dasar matapelajaran Pendidikan Pancasila dan Kewarganegaraan, dan ke kompetensi dasar matapelajaran Matematika. Sedangkan untuk kelas IV, V, dan VI, kompetensi dasar matapelajaran Ilmu Pengetahuan Sosial dan Ilmu Pengetahuan Alam masing-masing berdiri sendiri, sehingga pendekatan integrasinya adalah multi-disipliner, walaupun pembelajarannya tetap menggunakan tematik terpadu (Lampiran Permendikbud RI No.67 Tahun 2013).

Prinsip pengintegrasian inter-disipliner untuk matapelajaran Ilmu Pengetahuan Alam dan Ilmu Pengetahuan Sosial seperti diuraikan di atas dapat juga diterapkan dalam pengintegrasian muatan lokal. Kompetensi Dasar muatan lokal yang berkenaan dengan seni, budaya, keterampilan, dan bahasa daerah diintegrasikan ke dalam matapelajaran Seni Budaya dan Prakarya. Kompetensi Dasar muatan lokal yang berkenaan dengan olahraga serta permainan daerah diinte- grasikan ke dalam matapelajaran Pendidikan Jasmani, Olahraga dan Kesehatan(Lampiran Permendikbud RI No.67 Tahun 2013).

Selain itu acuan tentang pelaksanaan pendekatan pembelajaran tematik-terpadu untuk SD/MI juga disebutkan dalam Lampiran Permendikbud RI No. 65 Tahun 2013 tentang Standar Proses Pendidikan Dasar dan Menengah yang menyebutkan yakni:

Pembelajaran tematik-terpadu di SD/MI/ SDLB/Paket Adisesuaikan dengan tingkat perkembangan peserta didik....Proses pembelajaran sepenuhnya diarahkan pada pengembangan ketiga ranahtersebut (sikap, keterampilan, pengetahuan) secara utuh/holistik, artinya pengembangan ranah yang satu tidakbisa dipisahkan dengan ranah lainnya.Dengan demikian proses pembelajaransecara utuh melahirkan kualitas pribadi yang mencerminkan keutuhanpenguasaan sikap, pengetahuan, dan keterampilan.

Dalam lampiran Permendikbud RI No.67 Tahun 2013 diungkapkan yaitu ada lima faktor yang menjadi dasar pemerintah melakukan pengembangan Kurikulum 2013 yang disertai, salah satunya, dengan penetapan pendekatan pembelajaran tematik-terpadu untuk SD/MI, sebagai berikut : pertama, tantangan internal. Tantangan internal antara lain terkait dengan kondisi pendidikan dikaitkan dengan tuntutan pendidikan yang mengacu kepada 8 (delapan) Standar Nasional Pendidikan yang meliputi standar isi, standar proses, standar kompetensi lulusan, standar pendidik dan tenaga kependidikan, standar sarana dan prasarana, standar pengelolaan, standar pembiayaan, dan standar penilaian pendidikan. Tantangan internal lainnya terkait dengan perkembangan penduduk Indonesia dilihat dari pertumbuhan penduduk usia produktif. Saat ini jumlah penduduk Indonesia usia produktif (15-64 tahun) lebih banyak dari usia tidak produktif (anak-anak berusia 0-14 tahun dan orang tua berusia 65 tahun ke atas). Jumlah penduduk usia produktif ini akan mencapai puncaknya pada tahun 2020-2035 pada saat angkanya mencapai $70 \%$. Olehsebab itu tantangan besar yang dihadapi adalah bagaimana mengupayakan agar sumberdaya manusia usia produktif yang melimpah ini dapat ditransformasikan menjadi sumberdaya manusia yang memiliki kompetensi dan keterampilan melalui 
pendidikan agar tidak menjadi beban.

Kedua, tantangan eksternal. Tantangan eksternal antara lain terkait dengan arus globalisasi dan berbagai isu yang terkait dengan masalah lingkungan hidup, kemajuan teknologi dan informasi, kebangkitan industri kreatif dan budaya, dan perkembangan pendidikan di tingkat internasional. Arus globalisasi akan menggeser pola hidup masyarakat dari agraris dan perniagaan tradisional menjadi masyarakat industri dan perdagangan modern seperti dapat terlihat di World Trade Organization (WTO), Association of Southeast Asian Nations (ASEAN) Community, Asia-Pacific Economic Cooperation (APEC), dan ASEAN Free Trade Area (AFTA). Tantangan eksternal juga terkait dengan pergeseran kekuatan ekonomi dunia, pengaruh dan imbas teknosains serta mutu, investasi, dan transformasi bidang pendidikan. Keikutsertaan Indonesia di dalam studi International Trends in International Mathematics and Science Study (TIMSS) dan Program for International Student Assessment (PISA) sejak tahun 1999 juga menunjukkan bahwa capaian anak-anak Indonesia tidak menggembirakan dalam beberapa kali laporan yang dikeluarkan TIMSS dan PISA. Hal ini disebabkan antara lain banyaknya materi uji yang ditanyakan di TIMSS dan PISA tidak terdapat dalam kurikulum Indonesia.

Ketiga, Kurikulum 2013 dikembangkan dengan penyempurnaan pola pikir sebagai berikut:

a. Pola pembelajaran yang berpusat pada guru menjadi pembelajaran berpusat pada peserta didik. Peserta didik harus memiliki pilihanpilihan terhadap materi yang dipelajari untuk memiliki kompetensi yang sama.

b. Pola pembelajaran satu arah (interaksi guru-peserta didik) menjadi pembelajaran interaktif (interaktif guru-peserta didikmasyarakat-lingkungan alam, sumber/ media lainnya).

c. Pola pembelajaran terisolasi menjadi pembelajaran secara jejaring (peserta didik dapat menimba ilmu dari siapa saja dan dari mana saja yang dapat dihubungi serta diperoleh melalui internet).

d. Pola pembelajaran pasif menjadi pembelajaran aktif-mencari (pembelajaran siswa aktif mencari semakin diperkuat dengan model pembelajaran pendekatan sains).

e. Pola belajar sendiri menjadi belajar kelompok (berbasis tim).

f. Pola pembelajaran alat tunggal menjadi pembelajaran berbasis alat multimedia.

g. Pola pembelajaran berbasis massal menjadi kebutuhan pelanggan (users) dengan memperkuat pengembangan potensi khusus yang dimiliki setiap peserta didik

h. Pola pembelajaran ilmu pengetahuan tunggal (monodiscipline) menjadi pembelajaran ilmu pengetahuan jamak (multidisciplines); dan

i. Pola pembelajaran pasif menjadi pembelajaran kritis.

Keempat, penguatan tata kelola kurikulum. Pelaksanaan kurikulum selama ini telah menempatkan kurikulum sebagai daftar matapelajaran. Pendekatan Kurikulum 2013 untuk Sekolah Dasar/Madrasah Ibtidaiyah diubah sesuai dengan kurikulum satuan pendidikan. Oleh karena itu dalam Kurikulum 2013 dilakukan penguatan tata kelola sebagai berikut: tata kerja guru yang bersifat individual diubah menjadi tata kerja yang bersifat kolaboratif; penguatan manajeman sekolah melalui penguatan kemampuan manajemen kepala sekolah sebagai pimpinan kependidikan (educational leader); dan penguatan sarana dan prasarana untuk kepentingan manajemen dan proses pembelajaran. Sedangkan faktor kelima, penguatan materi. Penguatan materi dilakukan dengan cara pendalaman dan perluasan materi yang relevan bagi peserta didik.

Dari uraian di atas dapat dipahami bahwa kebijakan pemerintah tentang pendekatan pembelajaran tematik-terpadu di SD/MI yakni dilakukan dari kelas I hingga kelas VI yang disesuaikan dengan tingkat perkembangan peserta didik.Pembelajaran tematik terpadu untuk SD/ MI merupakan pendekatan pembelajaran yang mengintegrasikan berbagai kompetensi dari berbagai matapelajaran, terkecuali Pendidikan Agama dan Budi Pekerti, ke dalam berbagai tema dengan menggunakan empat pendekatan, yaitu intra-disipliner, inter-disipliner, multi-disipliner, dan trans-disipliner sehingga mampu memberikan makna yang utuh kepada peserta didik. 


\section{Relevansi Kebijakan Pembelajaran Tematik-Terpadu Terhadap Pemenuhan Kebutuhan Perkembangan Peserta Didik SD/MI}

Dari sisi konten kebijakan, penetapan penggunaan pendekatan pembelajaran tematikterpadu adalah sebuah langkah yang positif yang dilakukan oleh pemerintah dalam upaya perbaikan mutu pendidikan dasar di Indonesia, terutama pada jenjang Sekolah Dasar/Madrasah Ibtidaiyah. Sebagaimana disebutkan dalam lampiran Permendikbud RI No. 67 Tahun 2013 maupun Permendikbud RI No. 65 Tahun 2013 bahwa pembelajaran di SD/MI menggunakan pendekatan tematik-terpadu untuk semua mata pelajaran dari kelas I hingga kelas VI, terkecuali Pendidikan Agama dan Budi Pekerti. Hal ini menjadi sebuah kebijakan yang positif karena selaras dengan kebutuhan, karakteristik, dan tugas perkembangan peserta didik SD/MI. Atau dalam istilah Hamzah B. Uno dan Nurdin Mohammad yakni jika proses pembelajaran didasari oleh pemahaman dan pemenuhan kebutuhan perkembangan peserta didik maka proses tersebut akan memberikan layanan yang tepat dan bermanfaat bagi masing-masing siswa (Uno dan Mohamad, 2011:261).

Pendekatan pembelajaran tematik-terpadu untuk SD/MI dalam Kurikulum 2013 yang menggunakan pendekatan pengintegrasian yaituintra-disipliner, inter-disipliner, multi-disipliner, dan trans-disiplinerinimenjadikan pengalaman yang diberikan kepada peserta didik utuh dan lebih bermakna. Ditambah lagi peserta didik akan memahami konsep-konsep yang mereka pelajari itu melalui pengamatan langsung dan menghubungkannya dengan konsep lain yang sudah mereka pahami. Hal ini selaras dengan pendapat Piaget bahwa proses belajar dapat berlangsung jika terjadi proses pengolahan data yang aktif di pihak pembelajar. Pengolahan data yang aktif merupakan aktivitas lanjutan dari kegiatan mencari informasi dan dilanjutkan dengan kegiatan penemuan (Madjid, 2014:7).

Dewey juga mengungkapkan bahwa " $E d$ ucation is growth, development, life”. Hal ini berarti bahwa proses pendidikantidak mempunyai tujuan di luar dirinya, tetapi terdapat dalam pendidikan itu sendiri. Proses pendidikan juga bersifat kontinu yang merupakan reorganisasi, rekonstruksi, dan pengubahan pengalaman hidup, dan juga perubahan pengalaman hidup (Madjid, 2014:8).

Dalam pendekatan tematik-terpadu, tema merajut makna berbagai konsep dasar sehingga peserta didik tidak belajar konsep dasar secara parsial. Kegiatan pembelajaran justru memberikan makna yang utuh kepada peserta didik seperti tercermin pada berbagai tema yang tersedia. Kegiatan pembelajaran seperti ini sejalan dengan kecenderungan peserta didik SD/MI yang mempunyai tiga karakteristik utama dalam belajar yaitu: konkret, integratif, dan hierakhis (Rusman, 201:251-252).Selain itu, dunia anak adalah dunia nyata dan tingkat perkembangan mental anak selalu dimulai dari tahap berpikir nyata dalam kehidupan sehari-hari yang memandang objek yang ada di sekelilingnya secara utuh. Untuk itu, pembelajaran hendaknyadari lingkungan terdekat, yaitu mulai dari diri sendiri kemudian dikembangkan kepada keluarga dan sekolah (Susanto, 2013:72).

Penggunaan pendekatan pembelajaran tematik-terpadu bagi peserta didik SD/MI juga sesuai dengan pendapat Kolb dalam Malcolm Tight, bahwa belajar adalah proses pengetahuan dikreasi melalui transformasi pengalaman. Belajar adalah kebutuhan dalam kehidupan manusia sama pentingnya seperti bekerja dan berteman (Trianto, 2012:20).

Sementara itu, jika mencermati tentang prinsip pembelajaran tematik-terpaduyaitu: pertama, pembelajaran tematik-terpadu memiliki satu tema yang aktual, dekat dengan dunia siswa dan ada dalam kehidupan sehari-hari; kedua, pembelajaran tematik-terpadu perlu memilih materi beberapa mata pelajaran yang mungkin saling terkait; ketiga, pembelajaran tematikterpadu tidak boleh bertentangan dengan tujuan kurikulum yang berlaku tetapi sebaliknya harus mendukung pencapaian tujuan utuh kegiatan pembelajaran yang termuat dalam kurikulum; keempat, matei pembelajaran dapat dipadukan dalam satu tema selalu mempertimbangkan karakteristik siswa; dan kelima, materi pelajaran yang dipadukan tidak terlalu dipaksakan, maka sangat jelas terlihat bahwa pendekatan ini relevan dengan kecenderungan perilaku peserta didik SD/MI sebagaimana diungkapkan Rusman yakni: pertama, anak mulai memandang dunia secara obyektif, bergeser dari satu aspek ke aspek lain secara reflektif dan memandang 
unsur-unsur secara serentak. Kedua, anak mulai berpikir secara operasional; keempat, anak mampu megunaka cara berpikir operasional untuk mengklasifikasikan benda-benda; dan kelima, anak dapat memahami konep substansi, panjang, lbar, luas, tingi, rendah, ringan, dan berat (Rusman, 2010:251).

Hal yang sama juga dikemukakan oleh Rudy Gunwan bahwa proses pembelajaran di SD bergerak dari hal-hal yang konkrit ke halhal yang abstrak. Ia mencontohkan dalam pembelajaran IPS SD, salah satu pola yang dapat digunakan yaitu dengan pola pendekatan lingkungan yang meluas (expanding environment approach) dan pendekatan spiral yaitu dari mulai yang mudah kepada yang sukar, dari yang sempit ke yang luas, dan seterusnya (Gunawan, 2013:82-83).

Dari uraian tersebut dapat dipahami bahwa kebijakan penetapan pendekatan pembelajaran tematik-terpadu dengan segala prinsip dan karakteristiknya ternyata relevan dengan kebutuhan dan karakteristik perkembangan peserta didik SD/MI. Relevansi tersebut tampak dari pemaduan berbagai matapelajaran dengan suatu tema yang aktual dan dekat dengan kehidupan peserta didik. Kemudian, model pembelajaran melalui pengalaman langsung yang dikembangkan dalam pendekatan pembelajaran tematikterpadu menjadikan embelajaran lebih efektif dan lebih bermakna bagi peserta didik. Selain itu, pengintegrasian ketiga ranah pembelajaran yang meliputi aspek sikap, ketrampilan, dan pengetahuan dalam semua mata pelajaran menjadikan pendekatan tematik-terpadu menjadi semakin relevan dengan kebutuhan perkembangan peserta didik SD/MI yang juga mencakup kemampuan kognitif, kemampuan afektif, dan kemampuan psikomotor. Dengan demikian, secara konten kebijakan penetapan penggunaan pendekatan pembelajaran tematik-terpadu di SD/MI adalah tepat karena sudah sesuai dengan karakteristik perkembangan peserta didik.

\section{PENUTUP}

Berdasarkan pembahasan di atas dapat ditarik kesimpulan sebagai jawaban dari tiga rumusan masalah di awal artikel ini yaitu sebagai berikut: pertama, karakteristik perkembangan peserta didik di SD/MI dapat dipilah menjadi dua macam yaitu perkembangan pada aspek jasmaniah dan perkembangan pada aspek mental. Pada aspek jasmaniah, peserta didik SD/MI telah memiliki kematangan sehingga mampu mengontrol tubuh dan keseimbangannya. Pada aspek mental yang meliputi perkembangan inteletual, bahasa, sosial, emosi, dan moral keagamaan, peserta didik SD/MI secara intelektual berada pada tahap perkembangan operasional konkret (kelas I-V) dan operasional formal (kelas VI), yang memiliki kecenderungan belajar bersifat konkret, integratif, dan hierarkhis. Dari aspek bahasa, mereka telah mampu membuat kalimat sempurna, bahkan kalimat majemuk, dan juga dapat mengajukan pertanyaan. Dari aspek sosial, peserta didik di SD/MI mulai membentuk ikatan baru dengan teman sebaya dan mulai mampu menyesuaikan diri sendiri kepada sikap bekerjasama. Mereka secara emosi juga telah mulai belajar mengendalikan dan mengontrol ekspresi emosinya. Sedangkan pada aspek moral, peserta didik SD/MI sudah dapat mengikuti peraturan atau tuntuntan dari orangtua atau lingkungannya , bahkan di akhir jenjang SD/MI juga mampu memahami alasan yang mendasari suatu peraturan. Kedua, kebijakan pemerintah tentang pendekatan pembelajaran tematik-terpadu di SD/MI yakni dilakukan dari kelas I hingga kelas VI yang disesuaikan dengan tingkat perkembangan peserta didik. Pembelajaran tematik terpadu untuk SD/MI merupakan pendekatan pembelajaran yang mengintegrasikan berbagai kompetensi dari berbagai matapelajaran, terkecuali Pendidikan Agama dan Budi Pekerti, ke dalam berbagai tema dengan menggunakan empat pendekatan, yaitu intradisipliner, inter-disipliner, multi-disipliner, dan trans-disipliner sehingga mampu memberikan makna yang utuh kepada peserta didik. Ketiga, kebijakan penetapan pendekatan pembelajaran tematik-terpadu dengan segala prinsip dan karakteristiknya ternyata relevan dengan kebutuhan dan karakteristik perkembangan peserta didik SD/MI. Relevansi tersebut tampak dari pemaduan berbagai matapelajaran dengan suatu tema yang aktual dan dekat dengan kehidupan peserta didik. Kemudian, model pembelajaran melalui pengalaman langsung yang dikembangkan dalam pendekatan pembelajaran tematikterpadu menjadikan pembelajaran lebih efektif dan lebih bermakna bagi peserta didik. Selain 
itu, pengintegrasian ketiga ranah pembelajaran yang meliputi aspek sikap, ketrampilan, dan pengetahuan dalam semua mata pelajaran menjadikan pendekatan tematik-terpadu menjadi semakin relevan dengan kebutuhan perkembangan peserta didik SD/MI yang juga mencakup kemampuan kognitif, kemampuan afektif, dan kemampuan psikomotor. Dengan demikian, secara konten kebijakan penetapan penggunaan pendekatan pembelajaran tematik-terpadu di $\mathrm{SD} / \mathrm{MI}$ adalah tepat karena sudah sesuai dengan karakteristik perkembangan peserta didik.

$$
--000--
$$

\section{DAFTAR PUSTAKA}

Ali, Mohammad. (2009).Pendidikan untuk Pembangunan Nasional. Bandung: Imperial Bhakti Utama.

Fadjar, A. Malik. (1999).Madrasah dan Tantangan Modernitas, Cet. II, Bandung: YASMIN Bekerjasama dengan Mizan.

Gunawan, Rudy. (2013).Pendidikan IPS: Filosofi, Konsep dan Aplikasi, Cet. II. Bandung: Alfabeta.

Karwati, Euis, dan Donni Juni Priansa. (2013). Kinerja dan Profesionalisme Kepala Sekolah: Membangun Sekolah yang Bermutu. Bandung: Alfabeta.

La Iru dan La Ode Safiun Arihi. (2012). Analisis Penerapan Pendekatan, Metode, Strategi, dan Model-Model Pembelajaran.. Yogyakarta: Multi Presindo.

Madjid, Abdul (2014).Pembelajaran TematikTerpadu. Bandung: Remaja Rosdakarya.

Peraturan Pemerintah Nomor 32 Tahun 2013 tentang Perubahan Atas Peraturan Pemerintah Nomor 19 Tahun 2005 tentang Standar Nasional Pendidikan

Permendikbud RI Nomor 65 Tahun 2013 tentang Standar Proses Pendidikan Dasar dan Menengah

Permendikbud RI Nomor 67 Tahun 2013 tentang Kerangka Dasar dan Struktur Kurikulum Sekolah Dasar / Madrasah Ibtidaiyah
Prastowo, Andi (2013). Pengembangan Bahan Ajar Tematik. Yogyakarta: Diva Press.

Rusman, (2010). Model-Model Pembelajaran: Mengembangkan Profesionalisme Guru, Jakarta: Rajawali Pers.

Sani, Ridwan Abdullah (2013). Inovasi Pembelajaran. Jakarta: Bumi Aksara.

Santrock, John W. (2007). Psikologi Pendidikan, Edisi Kedua. Jakarta: Kencana Prenada Media Group.

Suryadi, Ace, dan Dasim Budimansyah. (2009). Paraigma Pembangunan Pendidikan Nasional: Konsep, Teori dan Aplikasi dalam Analisis Kebijakan Publik. Bandung: Widya Aksara Press.

Susanto, Ahmad. (2013). Teori Belajar dan Pembelajaran di Sekolah Dasar. Jakarta: Kencana Prenada Media Group.

Trianto. (2012)Mengembangkan Model Pembelajaran Tematik, Cet. III. Jakarta: Prestasi Pustakaraya.

Uno, Hamzah B., dan Mohamad, Nurdin (2011). Belajar dengan Pendekatan Pembelajaran Aktif Inovatif Lingkungan Kreatif Efektif, Menarik, Cet. II. Jakarta: Bumi Aksara.

Zamroni (2011).Dinamika Peningkatan Mutu. Yogyakarta: Gavin Kalam Utama. 